\title{
Asghar Wajahat's Unborn in Lahore and Salman Khurshid's Sons of Babur: Rehistoricising the Hindu-Muslim Rivalry
}

\author{
Joydeep Bhattacharyya \\ Assistant Professor of English, Kurseong College, Darjeeling, India. orcid.org/oooo-oooz- \\ 0329-3756. Email: b_joydeep31@rediffmail.com
}

Received October 30, 2017; Revised November 20, 2017; Accepted November 30, 2017; Published December o9, 2017.

\begin{abstract}
Indian theatre, after Independence, often engages with contentious issues, though squeamishness about communal realities, particularly the Hindu-Muslim relations and politics, seems to persist. Asghar Wajahat's Unborn in Lahore and Salman Khurshid's Sons of Babur are two examples where Indian theatre daringly questions the Islamised and the Hinduised characters of Pakistan and India respectively, confronting the communalised Hindu-Muslim identities and relations head-on. In the present study, it remains to be seen how the two plays interrogate the narrative of arch-rivalry between the two communities and, by extension, the two countries, whose present is always haunted by the spectre of past. The study aims to see how the 'true' history of communal rivalry has been reread by 'false' history in the plays; how the rereading rehistoricises the naturalised rivalry; and how the plays empower the suppressed voices of harmony, enriching a theatrical tradition of critique and plurality.
\end{abstract}

Keywords: Hindu, Muslim, India, Pakistan, partition, Indian theatre.

\section{Introduction}

Indian theatre, down the decades after Independence, becomes a reliable vehicle of the voices marginalised and a space to question 'everything that goes without saying' in the micro and macro levels of our society. The postcolonial spirit of critique produces a tradition of theatre that deals with several contentious issues of the newly born nation. But despite the growth of onstage critical tradition, there remains a persisting squeamishness about issues such as communal experiences and Hindu-Muslim relations. Indian theatre often produces remarkable engagements with sexuality, gender, caste, urban life, and the nation-state, but strikingly seems to downplay the ever contentious issue of Hindu-Muslim relations, except for few examples. The present study takes up two such examples - Asghar Wajahat's Unborn in Lahore (1988) and Salman Khurshid's Sons of Babur (2008). ${ }^{1}$ Wajahat's play questions the perceived monolith of a Muslim society vis-àvis the minority Hindu in the newly created/independent Pakistani state loaded with Islamised zeal. The play upholds the alternative voices that challenge religious essentialism and dismiss any notion of 'natural' enmity between the two largest religious communities in the sub-continent. Sons of Babur, despite its theatrical weaknesses as a play, revisits the history of Mughal India and uses it as a trope to examine the idea of India as a nation increasingly marked by religious intolerance and majoritarian politics. Both the plays negotiate popular history and stage the alternatives which are equally convincing, though sidelined in the majoritarian narratives of the two nation-states. The two plays offer occasions where the 'official' history of Islamic Pakistan and

(c) AesthetixMS 2016. This Open Access article is published under a Creative Commons Attribution Non-Commercial 4.0 International License (http://creativecommons.org/licenses/by-nc/4.o/), which permits non-commercial re-use, distribution, and reproduction in any medium, provided the original work is properly cited. For citation use the DOI. For commercial re-use, please contact editor@rupkatha.com. 
Hindu-majority India (not Hindu India due to its secular Constitution and democratic governance) is boldly challenged, thus enriching a not-so-rich tradition in Indian theatre where theatre boldly takes on communal issues. The present study seeks to understand the plays' engagement with the contemporary history of communal identities and relations in the two countries, while remaining informed of the visible interrelation of text and context or drama and history in them, i.e. drama's rootedness in the context which it comes from and also mediates by its act of redescribing that context.

\section{Text and context / drama and history}

Since the plays in question contest dominant history and offer alternatives, it is imperative to understand the complex and undeniable interface between post-Independence Indian theatre and the newly arrived socio-historical situation of the country. Theoretically, this calls attention to the new historicist interrelation of text and context or more specifically literature and history, where both are inseparable and embedded into each other (Brannigan, 1999). Poststructuralist destabilisation of history leads to the assumption of historicity of text and textuality of history. Literary text comes to be seen as a cultural form alongside many other such forms (texts) which constitute the context or the sociohistorical background. A literary text comes from its context, creating historicity of the text, and goes back to that context either to reinstate or to subvert it, resulting in textuality of history. The context (history) is continuously made/remade/unmade like the text in question. Such attempts to read a text to find how it is produced by its context and mediates that context as well offer alternative stories of the context. Such reading of text eventually discovers the 'contestability' of context or history. As a result, the boundaries of 'fictionalised history' and 'official history' become blurred, resulting in a debate over 'true' history and 'false' history.

\subsection{Post-1947 Indian drama and its context}

Indian theatre of today has its trajectory of development that began with and runs parallel to the socio-political history of the independent nation-state. It is a product of the post-Independence condition and remains a prioritised form, among other cultural forms, to mediate that condition. Reorientation of Indian theatre had started with the IPTA (Indian People's Theatre Association) since 1943, but a newly formulated modernity arrived in theatre only after the independence. This modernity can be seen in different aspects of dramatic techniques, conventions, themes, and overall ambience of theatre. This "general upsurge" (Dharwadker, 2007, p. 35) initiates a new culture of theatre which redirects theatre to an awareness of the newly emerged or emerging situation in the country. Theatre overhauls itself to come to terms with the volatile present that is marked by the opposing moods of nationalistic euphoria and sceptical or critical introspection. The stage increasingly comes close to the society and stands at a place where the two can 'talk' to each other. This role of theatre as a product and mediator of the society and the state helps Indian theatre, after the independence, evolve with a sustained desire for thematic and performative innovations and boldness.

\subsection{The postcolonial stage}

The post-Independence condition, which the reoriented theatre is born of and also engages with, is postcolonial as well. The Indian condition after the independence largely displays the general trend of the newly independent colonies in Asia and Africa, where "the project of becoming postcolonial [. . .] has usually been commemorated and legitimated through the foundation of independent nation-States" (Gandhi, 2001, pp. 110-11). Indian postcoloniality is evident in the post- 
Independence decolonisation drive to build a strong nation-state, which is culturally rooted and also 'modern' in its welfare character, though its modernity ironically rests on the western model of nation-state. Precolonial cultures and traditions have been invoked to fit into the framework of a modern state. As a result of this state-endorsed narrative of nation-building, the nation-state has decolonised itself to a great extent on the political, economic, and cultural fronts, though it might have failed to do so on many other fronts and succumbed to "replaying" (Nair, 2002, p. 245) and "recycling" (Bayly, 2005, p. 275) of the colonial style of thought and operation. On the positive note, the achieved decolonisation builds a national/istic sense of indigenousness and also creates a modern welfare state - things which were not possible under the colonial rule. But Indian postcoloniality does not limit itself to founding a politically-culturally confident nation-state which is capable of the most 'modern' way of governance possible. It extends further to have a space where a critical discourse has been developed to critique the state-endorsed discourse of decolonisation and nation-building. So, the narrative of constructing a modern, indigenous nation-state, which is postcolonial, has also been subjected to scrutiny under the postcolonial impulse. Postcolonialism, which calls for building a strong nation-state, questions the very process of that build-up. This counter discourse delimits the space for debate over the state, the nation, and its people and thus raises the voices hitherto unheard and unheeded, rendering the singular post-Independence narrative plural and, again, postcolonial.

Indian theatre, as a product of the postcolonial situation after Independence, interfaces with the situation. Theatre aspires to become decolonised, indigenised, and 'national', as articulated by the Sangeet Natak Akademi (SNA)-organised drama seminar of 1956. The desire is to formulate a new tradition of theatre for the newly born nation, though the effort, undertaken largely under the auspices of the "hegemonic state narrative of nationhood" (Sengupta, 2014, p. 19), tries to homogenise the multilingual, multicultural regional theatres by conflating them together to form a 'national theatre'. The effort undoubtedly produces some brilliant works and brings many a forgotten performance traditions to the light. But it also undermines the distinctive character and importance of the regional traditions in its urgency to fuse them with the primary model of classical Sanskrit theatre and design the national theatre for the new nation-state. However, Indian theatre refuses to remain within the exclusive paradigm of national theatre and, slowly but steadily, develops an alternative tradition that challenges homogenisation of theatre and, by extension, singularisation of culture. Theatre, here, closely interfaces with the changing socio-historical condition, which it is born of and also critiques and influences. It remains 'historicised' inasmuch as it runs in tune with the history of nationalistic euphoria that growingly has to coexist with disenchantment and critical introspection. From its obsessive search for 'root', theatre in India comes to use the 'root' (or the search for it) to critique the time it lives in. It proves the textuality, hence tenability, of history of the time by offering alternative versions of history through its critique. This interrelation of drama and contemporary history is crucial in developing a tradition of postcolonial theatre that is self-consciously critical, bold, and thematically and even stylistically innovative. Such a tradition of theatre can produce plays that question powerful socio-political narratives, either in India or even in its partitioned neighbour.

\section{The Hindus and the Muslims: the narrative of rivalry}

The plays under discussion deal with the issue of Hindu-Muslim relations in the Indian subcontinent, which is partitioned into two competitively hostile countries, India and Pakistan, solely on their majoritarian religious characters. The transfer of power in 1947 comes with the wound of partition that has rendered nearly two million people dead, fourteen to sixteen million 
people displaced, eighty-three thousand to one-hundred thousand women raped, kidnapped, forcibly converted, and killed (Menon, 2013, p. 7; Ansari, 2017). Partition has left a legacy of horror, anger, and nostalgia that neither of the nations seems to have been able to recover from to date. It lives in the public and private memories of the people on both sides of the border and continues to dominate the relations between the two countries and their two major communities, the Hindus and the Muslims, who also happen to be the minorities in varying numbers in one or the country. In the context of post-partition hostilities between India and Pakistan with its ramifications in Hindu-Muslim relations in both these countries, the two plays, Unborn in Lahore and Sons of Babur address the question of being Hindu in Islamic Pakistan and Muslim in Hindumajority India and uphold Indian theatre's ability to engage with issues that are otherwise glossed over for fear of political incorrectness.

The narrative of Hindu-Muslim rivalry has always been political in character that consequently spreads to other levels of socio-cultural interaction and builds the dominant narrative of 'natural' rivalry. Political rivalry creates and sustains socio-cultural rivalry between the two communities since the time of Muhammad bin Qasim's invasion in $711 \mathrm{CE}$. It would be wrong to entirely ascribe the Hindu-Muslim tense relations of today to the colonial rule and the partition, though they have largely shaped the future course of the relations. The history of political rivalry dates back to the eighth century in particular and the subsequent centuries that have seen the series of invaders, such as Mahmud of Ghazni, Muhammad Ghori, Timur, Nader Shah, Ahmad Shah Abdali, leaving the Hindus in northern India stunned for centuries. In Alberuni's words, "Mahmud [of Ghazni] utterly ruined the prosperity of the country and performed those wonderful exploits by which the Hindus became like atoms, dust scattered in all directions, and like a tale of old in the mouth of the people" (1910, p. 22). The killing and plunder at the political level has left wide ramification in all other levels, posing the two sides as archrivals, despite the fact that they continue to live together in close socio-economic ties in nonpoliticised spaces for centuries. The political narrative of rivalry often proves strong enough to undermine the social proximity developed mostly at the personal level among them and turns the private/personal narrative of amity into that of enmity.

\subsection{The narrative of rivalry under colonialism}

Politicisation of Hindu-Muslim relations receives a unique dimension in the hand of the British, who do not miss to see the political scope in the strained relations between the two communities and recast it in an unprecedented manner to adopt 'divide-and-rule' as a state policy. The British rulers, who were hostile towards the Muslim nobility till the Mutiny of 1857, change their strategy as Muslims are no longer their challenger to the throne of power and become hostile towards the majority Hindus, who predominantly lead anticolonial movements. The Hindu predominance in nationalist movement vis-à-vis the Muslim disinterest in any Hindu-led movements is skilfully exploited by the British. They implement the divide-and-rule through "a range of bureaucratic measures ... [to sharply define] the antinomies of religious majority and minority" (Menon, 2013, p. 9) and let the two groups fight against each other. Sadly, the major Indian political powers seemingly consent to this communal design and let, again, the political narrative of rivalry rule over other non-politicised spheres of interrelations. The country witnesses the horror of partition as it is politically divided into two states, based on religion. The political enmity spoils the socioeconomic coexistence so much - and that is also for centuries, from Mahmud of Ghazni to the British - that B. R. Ambedkar favours the partition and observes: "It is only an unimaginative person who could fail to take notice of these factors or insist in the face of them that Pakistan means breaking up into two what is one whole" (1945, p. 48). 


\subsection{The narrative of rivalry after the partition}

The horror of partition, alongside the history of enmity, is a reality that haunts the two independent nations to date. Both the countries try to appropriate the partition to claim greater loss for one than the other and generate a national (read: political) narrative of communal rivalry against each other. Spectre of partition remains alive in issues such as Kashmir which largely shapes anti-Hindu/India narrative in Pakistan and, inversely, anti-Muslim/Pakistan narrative in India (Sengupta, 2017, p. 14). They try to mobilise their respective majority communities to sustain the narrative, and thus the age-old political history of rivalry, accentuated by the partition, still remains predominant. Under this dictum, Pakistan becomes synonymous with Islam or the more rigid form of it, and India, though officially secular, desires to be Hindu; and thus the two become 'natural' arch-rivals. In such communalised or communally polarised nation-states and societies, the majority always treat the minorities as second class citizens and wish them away. India witnesses the rise of the Hindu Right forces against the backdrop of a decadent political culture that thrives on communal balancing or minority appeasement, leaving the minorities uncertain before an assertive majority. Pakistan, on the other hand, presents a worse scenario where the state-endorsed Islamisation of social life renders the existence of non-Muslim citizenry questionable.

\section{Voices of amity}

But alongside the reality of partition and its lasting spectre, equally true are the voices of amity and coexistence which have been functional at the micro level of social/personal relations for centuries. Although they often prove less powerful than the political narrative of enmity, they have always been there active. As the history of religious conversion of the Hindus into Islam is multidimensional and not singularly an account of force (Ali, 1983, p. 16; Cohen, 2012, p. 20), the history of enmity is also layered, replete with many more histories submerged under dominant history. Alongside mass violence, alternative voices of sanity and cooperation are not totally nonexistent. They have been mostly marginalised in the political narrative of rivalry. But their presence, however less audible and powerful that may be, shows that the two communities continue to travel through the recorded account of violence and distrust and live in a mutual dependence for centuries and still at present in a nonpoliticised, noncommunalised social space. The notional impossibility of coexistence is often challenged by the alternative possibility of coexistence. The large bulk of partition literature of Saadat Hasan Manto, Ismat Chughtai and others rests on this possibility of harmony amid strong discord and distrust. The plays of Asghar Wajahat and Salman Khurshid, under discussion, are similar attempts at recovering communal sanity by exploring the crisis of minority in majoritarian societies.

\section{Unborn in Lahore: the play}

Unborn in Lahore (Jis Lahore Nai Dekhiya O Jamya Nai) tells the travails of a 65-70 year old Hindu woman who suddenly becomes an alien outsider in her hometown Lahore in Islamic Pakistan immediately after the partition. The woman (referred to, symbolically, as Mai, the mother) has been discovered by a Muslim refugee family from Lucknow (in India) in her haveli (mansion), which has been allocated to the family by the Custodian's Office, but which she refuses to leave, despite having lost her family in the riot. The struggle, which follows over her mansion between the helpless refugee family and the property-hungry rioters, reveals a different tale of the post- 
partition situation. The displaced family from Lucknow, who comes to occupy the haveli as their relocated shelter, becomes the defender of the Hindu woman, risking their own safety in communally polarised Lahore. In defiance of religious bigotry and criminal-communal nexus, Mai becomes an extremely popular figure in the Muslim neighbourhood which defies all, at the end, to arrange for a Hindu cremation for her in a place recently cleansed of its Hindu inhabitants. Through Mai's presence, the play shatters many a stereotype related to Islam, Pakistan, the partition, and the refugees and foregrounds an alternative discourse, suppressed under communal intolerance.

Asghar Wajahat creates a very calm, sombre air, heavy with the toll taken by partition, in the play. The air has been made melodiously painful by the shayeris (Urdu poetry) of Nasir Kazmi, a refugee and a poet, at the end of each scene. The shayeris compose a tune that weaves the varied pain of displacement and relocation together against the intriguing rioters and zealots. The shattering compulsion of partition suddenly renders people alien to their own land and home and makes them accept the unknown, which is also unwelcoming. The play upholds this pain of uncertainty, which affects mostly the common people of the society, through a technique of simple, low-key, yet poignant, perceptive, and even ironical statement. Struggle to negotiate the partition has been shown with shocking realities about communal frenzy and politics, the idea of home and belonging, and the mythic homeland for Muslims. Communal politics is also challenged through the simple and humane delineation of the domestic sphere of women, which moves on through feminine kinship, despite the crisis in the external male world. The play's dominant tone of sombre challenge to communal stereotypes prevails till the end in spite of unabated violence all around. This tone is well supported by the minimalist stage design. The images of a dilapidated mansion, a small tea shop, and a dull neighbourhood mostly under the dim light and with poignant shayeris go well with the overall tone of the play that talks simply, yet with profound insights.

\subsection{Shattering the mythic Muslim homeland: Pakistan}

Unborn in Lahore, first and foremost, seeks to shatter the claim about Pakistan as an Islamic El Dorado for the Muslims of undivided India and both the countries even after the partition. The idea of Pakistan was politically floated under the garb of religious brotherhood to ignite Muslim imagination at large, though its visible impact was limited within northern India. The notion was manufactured and successfully circulated that the Indian Muslims, dethroned by the British and doomed to exist under Hindu majority in post-British India, "needed a homeland for their protection and to fulfil their cultural and civilizational destiny" (Cohen, 2012, p. 2). The goal of 'homeland' was achieved after the bloodbath of partition, though the realisation of the ideal still remains a question. The play intervenes in this ideal of Muslim homeland and exposes the gap between ideality and reality. For the refugee family from Lucknow, the ideality begins to shatter right from the day they enter their allocated house in Pakistan. After having lost the place they lived for years, they have been given a house which is still not vacated and has an old Hindu woman who refuses to leave her home. They cannot understand in their wildest imagination that a Hindu can call Pakistan his/her home. The 'Muslim homeland' confuses them further with many more shocking realities that shatter their dream of having all on the other side of the border. The Sindhi Custodian Officer, who supervises the allocation of evacuee properties to the refugees from India, prefers the refugees of Sindhi origin to any others, though they all are Muslims (Unborn in Lahore, 2000, p. 85). The character of Pahalwan, a wrestler who played a leading role in riot, is to endanger the idea of Pakistan as a safe haven for Indian Muslims. As a Muslim League worker and a local goon in Lahore, his business is now to occupy the evacuee 
properties and profit from them. His greed for the twenty-two-room mansion of Mai is not ready to spare even the Muslim refugee family of Sikandar Mirza, who find themselves on a par with the Hindu, Mai, in Pakistan. No Muslim in this 'land of Islam' seems to be ready to bail Mirza out of the crisis. Further, life becomes torturous to the Mirza family who finds the allocated house and the city of Lahore unknown and hostile, in comparison with their Lucknow. The whole idea of Pakistan as an Islamic alchemy thus becomes a complete shambles, where the tag of Islam or, so to speak, the political presence of Islam, alone cannot synthesise the fissures within.

\subsection{Post-partition fissures within Pakistan}

The play critically looks at the issue of refugee in order to foreground the unending fissures that (un)welcomed the immigrant Muslims in Pakistan. Refugee crisis is perhaps the most visible disaster caused by the partition. In a never-seen-before migration in the recorded history of mankind, about sixteen million people moved across the border between the two newly born rival nations. Approximately five and half million Hindus and Sikhs had to move from western Punjab (fallen in Pakistan) to its eastern part (in India), and about six million Muslims the reverse way, i.e. from eastern Punjab to its western part (Talbot as cited in Menon, 2013, p. 34). The rail track from Sialkot to Amritsar was strewn with corpses, and the road from Amritsar to Lahore was converted into "a massive graveyard" (Talbot, 2009, p. 104). The population landscape of Amritsar and Lahore changed drastically; Lahore became cleansed of its Hindus and Sikhs who formed over a third of the population, whereas Muslims were virtually wiped out in Amritsar (Talbot as cited in Menon, 2013, p. 34). The arrival of refugees created further crisis in cities such as Lahore. Battered, split up and lost, the refugees had to encounter several problems, alongside governmental mismanagement of resettlement. Their arrival sparked off tension between them and the local Muslim residents; or sometimes between them and the Hindu minorities who delayed/refused to depart (Talbot, 2009, p. 105). Among all immigrants from India, the refugees from United Province (now Uttar Pradesh in India), numbering above four hundred thousand in total, faced the most critical situation. Like other refugees, they were also derogatively called Mohajirs (Muslim immigrants from India) by the local Muslims. But unlike other Mohajirs, their settlement was not easy and mostly remains so even to date in Sindh, where sixty percent of them came, and Punjab, which was hostile to them. Their pride over their pre-partition contribution to forming Pakistan was largely shattered by linguistic and cultural discriminations, as also by the unfriendly topography of their relocated land (Talbot, 2009, pp. 107-09). The life of Lahore was found to be in terrible contrast with that of Lucknow and Awadh, taking a heavy toll on the refugee life, socially and culturally.

\subsection{Challenging the political myth of Pakistan by private/personal realities}

Unborn in Lahore addresses the crisis of refugees, their displacement, relocation, and home, against the backdrop of 'natural' Hindu-Muslim rivalry, through a Muslim refugee family from Lucknow in United Province and a Hindu old woman, who is a potential evacuee in Lahore. Leaving home implies a sense of loss of all that are associated with the idea of 'home', such as "land, territory, neighbourhood, environs, community, citizenship" (Jain, 2016, p. 22). Conjunctively, a migration to a prospective home demands the compensatory substitution for all that are lost due to the migration. When demands are not fulfilled, myth shatters into pieces. The play takes up the crisis of refugees at a very personal and private level of experiences to question powerful political myth/s. The encounter between the Muslim refugee family and the Hindu old woman seeks to subvert many a stereotype regarding the Muslim refugees in their 'homeland' Pakistan, the to-be-evacuated Hindu minorities and, by extension, the idea of home vis-à-vis the Hindu-Muslim relations. The play begins with some prominent spectacles of partition; the 
politically mobilised euphoria for Pakistan is followed by the contrasting image of refugees, trudging across the stage. From this well known history of partition, the play enters into the domain of private, personal history, which is lesser-known and hence made lesser-important. The first thing the Mirza family discovers, after having landed in Pakistan, that they are unwelcome Mohajirs to the local population. They are, first, stunned by the presence of an 'enemy' (read: Hindu) in the house allocated to them. The Custodian Office offers no hope as it suffers from intrastate tension and regional prejudice within Pakistan. Stranded in a shared shelter with a Hindu, shaken off by an apathetic administration and intimidated by the property sharks masquerading as religion, the family has a lot of different tale to tell. An intimacy grows between the 'enemies' - Mai, the Hindu woman and the Muslim family. Importantly, the intimacy grows and works chiefly at the feminine, domestic level, in contrast to the external, male world of conflict. The women start interacting on small domestic details such as homemade medicines, kitchen essentials, spices with different names in Lahore and Lucknow. The discussion goes beyond kitchen to the city of Lahore, which Mai owns by her heart, and Lucknow, which the Mirza family is still fond of. The women reveal how difficult it is for people to negotiate a politically drawn border that changes home and location. Mai can convincingly claim the haveli to be her home and justify her claim by her proof of belonging to the home and Lahore at large. She thus dismisses the political idea of home that wants her (a non-Muslim) to quit Lahore (Pakistan) and the Mirzas to claim her haveli and call it home, instead of that which they have to leave in Lucknow. The irony that hits most the political narrative of refugee and home is that the Mirza family finally comes to defend the Hindu woman, whom they are supposed to evict, against the communal zealots. Personal narrative of a handful of ordinary people thus challenges the political narrative of Pakistan as the home of the Muslim refugees and not a place for the non-Muslims, alongside questioning the notion of 'natural' rivalry between the two communities.

\subsection{Exposing Islamised Pakistan}

In stark contrast to Mohammad Ali Jinnah's inaugural speech to the Constituent Assembly on 11 August 1947, envisioning a secular and modern state, Pakistan has slid into such a dark state that it is now being called "the most dangerous place in the world" (Cohen, 2012, p. 1). The possibility of, at least, an Indian type of democracy in the country has been crippled, right from its birth, by its foundational ideology of two-nation theory (Ali, 1983, p. 42). As a result, the country has been run by the "nexus between Islamist orthodoxy, military oligarchy and the feudal rich" (Sengupta, 2014, p. 25), which began most crudely under Zia-ul-Haque's presidency and made Pakistan, in Salman Rushdie's words, "a nightmarish, surreal land" (2010, p. 53), where most obsolete ideas of human history operated in a world of make-believe. Now globally branded as a safe haven of Islamist terrorism (Cohen, 2012, p. 1; Sengupta, 2014, p. 28), Pakistan epitomises the political narrative of Hindu-Muslim rivalry through state-endorsed Islamisation programme and encouragement to religious extremism. The state policy of intolerance and radicalisation has infected the social fabric, which is nakedly polarised across the powerful Muslim majority and the virtually non-existent, non-Muslim minorities, outrageously categorised by the state as dhimmi (non-Muslim taxpayers) (Talbot, 2009, p. 282). Unborn in Lahore looks at the radically Islamised society of Pakistan, which comes from the two-nation theory of Hindu-Muslim incompatibility. Characters such as Pahelwan become the custodians of religion, who cash in on communal hatred and use religion as a money-spinner by inventing 'imagined threat/s' to Islam. Their urge to evict Mai is more for the commercial merit of her property than for any holy vocation to religion; but the commercial conspiracy is given a religious-political colour. The old, helpless Hindu woman becomes a threat to Islam/Pakistan and invites jihad, which is for them the 'holy war against non- 
Muslims to defend religion'. Even Muslims, who stand opposed to this nexus between religionists, criminals, and politicians, are not spared in the 'land of Islam'.

\subsection{Challenging radicalised Islam}

While unfolding the tragedy of a communalised society, the play also pits political-radical Islam against a sane and harmonious version of the faith and exposes religiosity that masquerades as religion to have a grip on society. Religion is something which comes to a person not by choice but tradition; so Nasir Kazmi, the poet, finds it useless to fight against each other for a choice which is not self-made ( $U L, 2000$, p. 90). In the play, Maulana Ikramuddin is the most authoritative voice to challenge religious bigotry from within the establishment. From his mosque he makes it clear that Islam does not permit violence against somebody who seeks shelter and is helpless; more so, if that person is of another faith $(U L, 2000$, p. 89). Further, jihad should be waged against somebody's ego to cleanse him/her of communal hatred ( $U L$, 2000, p. 90). The play becomes most vocal against the narrative of hatred when the Muslim neighbourhood, under the auspices of Maulana Ikramuddin, comes together to arrange for the cremation of Mai according to the Hindu customs, chanting 'blasphemously' "Ram nam satya hai" (UL, 2000, p. 96). The maulana (Islamic religious scholar) is murdered at the end, but his pluralistic version of Islam challenges the "medieval, misogynistic, stultifying ideology" (Rushdie, 2010, p. 54) of radicalised Islam that bars interfaith harmony and spreads violence. Through the human tragedy taking place at a private level in a communalised society, the play upholds the alternative voices, suppressed under the political narrative of religious bigotry.

\section{Sons of Babur: the play}

Salman Khurshid's Sons of Babur explores the idea of post-1947 India in the context of its majoritarian society's growing uneasiness with its minorities. The play critically looks back at the grand narrative of history in order to read the growing fissures on the body of the nation at present. Instead of travelling along private or personal narrative, it remembers Mughal India (1526 - 1856 (E), from Babur to Bahadur Shah Zafar, and rereads the political history to reveal the dangers the nation is heading through communal politics. The history of the Mughals in India and India under them - their arrival, assimilation, rise and fall, and the ever sensitive issue of Hindu-Muslim relations - offers a political prototype of post-1947 India that also witnesses religious intolerance in its richly diverse and plural society.

Shift in time and space is important in the play as it captures Mughal India and Rangoon, where Bahadur Shah Zafar died in exile, along with the twenty-first century India in a compendium and travels freely between times and spaces. Zafar becomes a tool to travel to the past to understand the idea of India or Hindustan under the Mughals and its fall later under the British who banished Zafar to Rangoon. The play demands continuous change in setting to suit places such as Delhi, Agra, Rangoon, Rajputana, Deccan, Gujarat of the past and also a university campus of the present. Khurshid nicely negotiates the recurrent shift by dividing the stage into three parts; the left is kept for the university plaza and Student's Union Office, while the centre is to unfold the Mughal India and the right side to show Zafar in exile in Rangoon. The Pierrot's Troupe's production of the play, directed by M. Sayeed Alam, has used the right end and the space down between the stage and the audience for the university events, while putting Zafar to the left and the Mughals at the centre of the stage. 


\subsection{The Mughal India}

Through its well-thought technical layout, the play attempts to examine the secular credentials of India at present vis-à-vis its religio-administrative credentials under the Mughals. A university student, Rudranshu Mitra, wants to stage a play on Bahadur Shah Zafar as a protest against growing Hindu communalism and undertake a journey to Rangoon for research. Denied initially a university travel grant, he meets Zafar in trance or dream and travels through the Mughal era under the guidance of the last Mughal king. His dream-travel looks at the Mughals in a different perspective, where Babur and his descendents are not the savage plunderers such as Muhammad Ghori. They rather appear as the architects of an India of well-organised administration and religious confluence. India under them exemplifies a despotic yet benevolent rule, whose religioadministrative policies can be a paradigm to the post-1947 Indian state. Though India as a permanent residence was an anathema to Babur, he subsequently accepts this land and advises his son Humayun to be a part of it (Sons of Babur, 2012, p. 31). Akbar scripts the foundation of an India of communal harmony by adopting a tolerant policy towards the Hindus, especially through his modified and syncretic version of Islam, called Din-e-illahi, meaning 'the Religion of God' (SB, 2012, p. 49). But Akbar's India comes to be rejected by Aurangzeb, who wants to restore pristine Islam in India and make it Dar-ul-Islam, i.e. the land of Islam ( $S B, 2012$, p. 89). Aurangzeb's skill as an administrator is undermined by his religious intolerance towards the Hindus, sounding the death knell for the empire. But even in their fall, the Mughals remain the symbolic centre of power and the emblem of an Indian state, which even the British cannot not ignore $(S B, 2012, \mathrm{p}$. 111). This legacy of the Mughal empire forces the sepoys of 1857 mutiny to choose Zafar as their leader and the British to exile this powerless 'king of India' to Rangoon to officially register their victory.

\subsection{Allegory of history to critique 'Hinduised' India of the present}

The play rediscovers the history of the consolidation of India, so to speak, Hindustan, under the Mughals, where Hindus and Muslims coexisted in a relatively peaceful condition. Its success lied chiefly in the religious tolerance of most of its rulers, while its fall was largely scripted by the absence of that tolerance. The play seeks to revive the memory of Zafar, who even in his wretchedness was once 'India' to the Indians (Hindus and Muslims alike) and the British. Zafar symbolises the secular credential of India, which is at stake now. The play uses history to question this crisis of the present. Independent India begins its journey with the long history of HinduMuslim rivalry on its back. Under the British who replaces the Islamic rule, the gulf widens due to the colonial strategy of communal manipulation, the Hindu character of the nationalist movement, and the Muslims' apathy towards the idea of a Hindu-majority undivided India. Partition displays the worst form of this rivalry, the spectre of which continues to shape the general Hindu attitude towards the Muslims in India. In addition to the burden of history, Nehruvian secularism also fails to achieve a political society, which is acommunal or neutral to communal politics. The postcolonial realities of identity politics on the basis of caste and creed have been mostly hijacked by vote-politics that rides on communal fervour to gain electoral advantage. This results in majoritarian and minoritarian politics, contaminating communal balance of the society. The rise of the Hindu right, or Hindutva, in reaction to the "state's pseudosecularist policy" (Menon, 2013, p. 104) of Muslim appeasement, recasts forever the relation between the two major communities in independent India. The assertive Hindu right questions the politics of secularism, which undermines Hindu interests, and goes to slam all Muslims as Babur ki aulad (sons of Babur), displaying the ugly height of majoritarian politics. The entire political narrative becomes communalised, where the Muslims, as a whole, have been perceived 
as the living reminder of past pillages and plunders and, therefore, a constant threat to the Hindus. Equally, the Muslim sense of fear has been politically exploited to stoke up the counterpolitics of the minority, resulting in the radicalisation of their protest. In this context of growing communalisation that endangers Indian plurality, the play seeks to bring back the spirit of Zafar, as a symbol of Hindu-Muslim harmony, in India. It remembers the Mughals as largely the architects of India, as we see it at present, and revisits their rise and fall as an allegorical reminder of the importance of religious tolerance in present-day India.

\subsection{Where the play lacks in}

Sons of Babur, as a play, has numerous weaknesses in its thematic polemic. Reading history is as political as writing history. The play tries to reread the Mughal history in order to challenge the 'alienness' of Babur and his sons and show them as Indian emperors and thus answer the question over the 'Indianness' of Indian Muslims. Zafar, who is the chief medium of rereading history, is obviously biased towards his own dynasty; the other medium, Rudranshu, is not always a convincing filter to look through at history. Although it admits that history's meaning depends on perception which is also subject to sociohistorical condition $(S B, 2012, \mathrm{p} .48,52)$, the play's politics of rereading history creates some paradigms and takes them for truth. The 'truth' that the idea of India began only with the Mughals can be debatable $(S B, 2012$, p. 74); equally arguable are the claims about Akbar's liberalism and Aurangzeb's administrative skill ( $S B$, 2012, pp. 87-89). Contradiction is there when Zafar warns against judging the past by the present standards; the entire play rests on rereading the past from the perspective of present socio-historical condition and using it as trope to critique the present. Khurshid's political act of re/reading history seems to have been largely informed by his onus as a member/leader of Indian National Congress (INC) pitted against its arch-rival, the Hindu right Bharatiya Janata Party (BJP). Much is told by the dedication of the play, where Khurshid eulogises Sonia Gandhi, the INC president, as someone "whose tryst with destiny has an admirable commitment to the India that defines us" (SB, 2012, p. v) and dedicates the book to her.

\section{Conclusion}

The biggest hurdle to Hindu-Muslim relations seems to be the presence of the 'past'. The past remains legitimised in the 'official/true' histories that project the two communities as eternally locked in combat against each other. As a result, the spectre of enmity continues to impact issues at 'inter-national' level, such as Kashmir, as also at intranational level, such as the Hindu/Muslim minority in either of the states of India and Pakistan. What is lost in the metanarrative of political rivalry is the voice of the common people who might think differently and live in a world not guided by the equations of this politics of hatred. Asghar Wajahat's Unborn in Lahore empowers this marginalised voices to contest the 'past' and question some of history's popular 'truth/s' regarding the Muslims, the Hindus, Pakistan, and the partition; thus past (history) has been reviewed to rethink the present. Sons of Babur, on the other hand, contests history's onedimensional projections to challenge the majoritarian Hindu claim on India and argues for cultural plurality India still stands for. Both the plays thus contest 'true' history with 'false' history. They seem to have imbibed the postcolonial spirit of critiquing the 'given' and looking for alternatives. They look 'differently' at the issues of identity and relations between the Hindus and the Muslims and script alternative realities of the present by redescribing the past. The spectacles of the Hindu woman in a Muslim neighbourhood in Lahore and Bahadur Shah Zafar with a 
Hindu, university student in Rangoon offer such onstage moments of redescribing (read: rehistoricising), which, to use Rushdie, are necessary to change the world at hand (2010, p. 14).

\begin{abstract}
Notes
${ }^{1}$ Unborn in Lahore (Jis Lahore Nai Dekhiya O Jamya Nai) was premiered at Shri Ram Centre in New Delhi in 1989 under the direction of Habib Tanvir, and ever since it has travelled across the country and around the globe in several languages and has had more than one thousand performances (Bajeli, 2005). Sons of Babur was premiered at FICCI KK Birla Auditorium in New Delhi in 2010 under the direction of M. Sayeed Alam by Pierrot's Troupe and has been performed at some prestigious places in India and abroad (SB, 2012, p. xvi; Zaman, 2011).
\end{abstract}

\title{
References
}

Alberuni, A. M. (1910). Alberuni’s India. E. C. Sachau (Ed.). London, England: Kegan Paul, Trench, Trubner.

Ali, T. (1983). Can Pakistan survive? / The death of a state. Harmondsworth, England: Penguine Books.

Ambedkar, B. R. (1945). Pakistan or partition of India. Bombay, India: Thacker and Company Ltd.

Ansari, S. (2017, August 11). How the Partition of India happened - and why its effects are still felt today. Retrieved October 9, 2017 from http://www.independent.co.uk/news/long_reads/how-the-partition-ofindia-happened-and-why-its-effects-are-still-felt-today-a7888131.html

Bajeli, D. S. (2005, August 26). History's reflections. Retrieved October 17, 2017, from http://www.thehindu.com/ fr/2005/o8/26/stories/200508260239030o.htm

Bayly, S. (2005). Caste, society and politics in India: From the eighteenth century to the modern age. Cambridge, England: Cambridge University Press.

Brannigan, J. (1999). Introduction: History, power, and politics in the literary artifact. In J. Wolfreys (Ed.), Literary theories: A reader and guide (pp. 417-427). New York, NY: New York University Press.

Cohen, S. P. (2012). The idea of Pakistan. New Delhi, India: Oxford University Press.

Dharwadker, A. (2007). Communication. The Book Review, 31(2), 35-36.

Gandhi, L. (2001). Postcolonial theory: A critical introduction. New Delhi, India: Oxford University Press.

Jain, J. (2016). Lost homes, shifting borders, and the search for belonging. In A. Singh, N. Iyer, \& R. K. Gairola (Eds.), Revisiting India's partition: New essays on memory, culture, and politics (pp. 21-27). Lanham, MD: Lexington Books.

Khurshid, S. (2012). Sons of Babur / A play in search of India. New Delhi, India: Rupa Publications.

Menon, J. (2013). The performance of nationalism / India, Pakistan, and the memory of partition. Delhi, India: Cambridge University Press.

Nair, R. B. (2002). Lying on the postcolonial couch: The idea of indifference. New Delhi, India: Oxford University Press.

Rushdie, S. (2010). Imaginary homelands. London, England: Vintage Books.

Sengupta, A. (Ed.). (2014). Mapping South Asia through contemporary theatre / essays on the theatres of India, Pakistan, Bangladesh, Nepal and Sri Lanka. Hampshire, England: Palgrave Macmillan.

Sengupta, A. (Ed.). (2017). Islam in performance / Contemporary plays from South Asia. London, England: Bloomsbury.

Talbot, I. (2009). Pakistan / A modern history. London, England: Hurst \& Company.

Wajahat, A. (200o, September/October). Unborn in Lahore. The Little Magazine, 1(4), 82-98. 
Zaman, R. S. (2011, December 1). Dramatising history. Retrieved June 7, 2016, from http://www.thehindu.com/features/friday-review/theatre/dramatising-history/article2677683.ece

Joydeep Bhattacharyya teaches English literature, as an Assistant Professor, in Kurseong College since 2005. He wrote his M.Phil. dissertation (2000) on Robert Frost and obtained Ph.D. (2014) on the plays of Vijay Tendulkar and Girish Karnad. He has contributed articles, especially on Indian theatre, to several edited volumes and journals and authored the book, Robert Frost: The 'Dramatic' in Poetry (2017). 